Reprod. Nutr. Dévelop., 1987, 27 (2 A), 423-439.

\title{
In vitro effect of salmon gonadotropin on the testicular synthesis of androgens and of a progestin, $17 \alpha$-hydroxy-20 $\beta$-dihydroprogesterone, in the rainbow trout (Salmo gairdneri)
}

\author{
A. SAAD, J. DÉPÊCHE
}

Laboratoire de Physiologie de la Reproduction des Vertébrés, Université P.-et-M. -Curie, 4, place Jussieu, 75252 Paris Cedex 05.

Summary. In vitro, a highly purified fraction of salmon gonadotropin $(10 \mathrm{ng} / \mathrm{ml}, 3 \mathrm{~h}$ incubation, $16{ }^{\circ} \mathrm{C}$ ) increased both 11 -oxotestosterone and $17 \alpha$-hydroxy-20 $\beta$-dihydroprogesterone $(17 \alpha-20 \beta$ P) production in the rainbow trout testis. However, the synthesis of the progestin appeared preferentially favoured. After a reexamination of the biosynthetic routes for androgens and $17 \alpha-20 \beta \mathrm{P}$, using radiochromatographic methods, the effect of the gonadotropin on the conversion of pregnenolone, progesterone and $17 \alpha$-hydroxyprogesterone was studied. This study indicated the existence of a pleiotropic action of the hormone on the enzyme activities of the steroidogenic pathway in the testis. The following enzymatic steps appeared under a positive gonadotropic control : formation of pregnenolone, conversion of $\Delta 5$ into $\Delta 4$ steroids $(\Delta 5-3 \beta$-OHSOR activity), $17 \alpha$-hydroxylation of progesterone, $20 \beta$-oxidoreduction and 17-20 cleavage of $17 \alpha$-hydroxyprogesterone. The favoured synthesis of $17 \alpha-20 \beta \mathrm{P}$ (that was not converted into androgens by 17-20 lyase activity) appeared as a consequence of a differential pattern of gonadotropin action on a multienzymatic positive control system. It did not involve the inhibition of any biosynthetic step leading to a shift in the steroidogenic pathway.

\section{Introduction.}

In teleost fishes, a single pituitary hormone, the so-called glycoprotein maturational gonadotropic hormone $(\mathrm{GTH})$, is assumed to control the steroidogenic activity of the gonads (Idler and $\mathrm{Ng}, 1983$ ). Gonadal steroid production does not obey a simple and easily generalizable pattern in all species ; on the contrary, it exhibits considerable diversity (Fostier et al., 1983). In male rainbow trout, 11-oxygenated androgens, and, in particular, 11-oxotestosterone, are major end-products of the testicular steroidogenic pathway, as in a number of other species (Arai and Tamaoki, 1967 ; Ozon, 1972 ; Kime and Hews, 1978 ; Fostier et al., 1983). In addition, it has been shown that a progestin, $17 \alpha$-hydroxy$20 \beta$-dihydroprogesterone $(17 \alpha-20 \beta \mathrm{P})$, is another major testicular steroid (Arai and Tamaoki, 1967 ; Kime, 1979 ; Dépêche and Sire, 1982). The testicular ratio of 11-oxotestosterone $/ 17 \alpha-20 \beta \mathrm{P}$ production varies at the different stages of the annual reproductive cycle, as shown by changes in the plasma concentrations of these two steroids (Scott and Baynes, 1982 ; Baynes and Scott, 1985) and their 
apparent rates of synthesis from labelled precursors in the testis in vitro (Dépêche and Sire, 1982). At terminal stages of the spermatogenetic cycle, there is a significant increase in the testicular secretion of $17 \alpha-20 \beta \mathrm{P}$, perhaps in relation to spermiation processes (Ueda et al., 1983, 1984); this increase is concomitant with a rise of plasma GTH concentration (for references, see Ueda et al., 1983). In the rainbow trout, it has been established that testicular production of 11-oxotestosterone is controlled by GTH (Ng and Idler, 1980 ; Ueda et al., 1984). A GTH effect on testicular production of $17 \alpha-20 \beta \mathrm{P}$ was also demonstrated in other works (Ueda et al., 1983, 1984). In this species, the gonadotropic stimulation of the testis appears to induce asynchronous modulations of androgen and progestin productions. The possibility that one gonadotropin can act upon the steroidogenic pathway according to preferential mechanisms is an interesting problem in comparative endocrinology. No strickly comparable pattern of changes in testicular steroidogenesis under gonadotropin action seems to have been described yet in other Vertebrates.

In order to analyse the effect of gonadotropic stimulation on testicular steroidogenesis in rainbow trout, in the present work, we have studied the action of a highly purified fraction of salmon gonadotropin, prepared from the hypophysis of Oncorhynchus tschawytsha (onc-GTH), on the production of both 11 -oxotestosterone and $17 \alpha-20 \beta \mathrm{P}$ by the testis in vitro. Furthermore, using various labelled $\Delta_{5}$ - and $\Delta_{4}$-steroids, we have attempted to specify the changes in enzyme activities induced by these hormones. This study required previous reexamination of steroid routes of biosynthesis in the rainbow trout testis.

\section{Material and methods.}

Animals. - Male rainbow trouts, in their second reproductive cycle, were obtained from the experimental fish farm of INRA at Jouy-en-Josas (France). After the fish were anesthetized with phenoxy-2-ethanol $(0.05 \%)$, the testes were removed and cut into 100 to $500 \mathrm{mg}$ slices for in vitro incubation. Fragments were also prepared for histological examination to determine the stage of spermatogenesis. The testes were incubated at stage VIII of the spermatogenetic cycle, according to the classification of Billard and Escaffre (1975) (gonadosomatic index of non-eviscerated animals : $1.63 \pm 0.62 ; n=26$ ). The germ cells contained in the testicular lobules were only primary spermatogonia (type $A$ ) and spermatozoa. Spermiation is initiated at this stage.

Radioactive steroids $\left(^{*}\right)$. - The different radiolabelled steroids were purchased from Amersham International and their purity was checked by thin-layer chroma-

$\left(^{*}\right)$ Steroid nomenclature and abbreviations: pregnenolone $(\Delta 5 \mathrm{P}): 3 \beta$-hydroxy-5-pregnen20 one ; $17(\alpha$-hydroxypregnenolone $(17(\alpha-\mathrm{OH} \Delta 5$ P) : $3 \beta-17 \alpha$-dihydroxy-5-pregnen-20-one ; dehydroepiandrosterone (DHEA) : 3 3 -hydroxy-androst-5-ene-17-one ; progesterone ( $44 \mathrm{P}): 4$-pregnene-3,20-

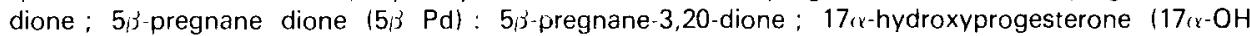

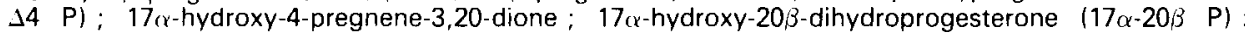
$17 \alpha, 20 \beta$-dihydroxy-4-pregnen-3-one ; androstenedione (14 A) : 4-androstene-3, 17-dione ; 11 $\beta$-hydroxyandrostenedione $(11 \beta-O H \quad \Delta 4 \quad A): 11 \beta$-hydroxy-4-androstene-3,17-dione ; testosterone (T): $17(x$-hydroxy-4-androsten-3-one; $11 / \beta$-hydroxytestosterone $(11 \beta \mathrm{OH} \mathrm{T}): 11 \beta, 17 \beta$-dihydroxy-4-androsten-3-one; androstenetrione (A-trione): 4-androstene-3,11,17-trione ; 11 -oxotestosterone (11 oxo T) : 173 -hydroxy-4-androstene-3,11-dione. 
tography: $\quad \Delta 5-7(\mathrm{n})-{ }^{3} \mathrm{H}$-pregnenolone $(10 \mathrm{Ci} / \mathrm{mmol}) ; 1.2 .6 .7 .{ }^{3} \mathrm{H}$-progesterone (96 Ci/mmol); $17 \alpha$-hydroxy-7(n)- ${ }^{3} \mathrm{H}$-progesterone $(10.7 \mathrm{Ci} / \mathrm{mmol}) ; 17 \alpha-4-{ }^{14} \mathrm{C}$ hydroxyprogesterone $(60 \mathrm{mCi} / \mathrm{mmol}) ; 1.2 .6 .7 .{ }^{3} \mathrm{H}$-androstenedione $(86 \mathrm{Ci} / \mathrm{mmol})$; $7(\mathrm{n})-{ }^{3} \mathrm{H}$-androstenedione $(15 \mathrm{Ci} / \mathrm{mmol}) ;\left[4-{ }^{14} \mathrm{C}\right]$ androstenedione $(50 \mathrm{mCi} / \mathrm{mmol})$; $1.2-{ }^{3} \mathrm{H}$-testosterone $(42 \mathrm{Ci} / \mathrm{mmol}) ;\left[4^{14} \mathrm{C}\right]$ testosterone $(50 \mathrm{mCi} / \mathrm{mmol})$; labelled $17 \alpha$-hydroxy-20 $\beta$-dihydroprogesterone was prepared from tritiated or ${ }^{14} \mathrm{C}-17 \alpha$ hydroxyprogesterone by action of $\mathrm{Na} \mathrm{B} \mathrm{H}_{4}$ at $0^{\circ} \mathrm{C}$, according to a modification of the technique of Norymberski and Woods (1955) due to Fostier (personal communication). The steroid was purified by successive chromatographies in 5 systems : benzene-acetone $80: 20$ (2 times) ; cyclohexane-ethyl acetate $40: 60$ (2 times) ; chloroform-ethanol $90: 10$; chloroform-methanol-water $90: 9: 1$ : benzene-acetone $80: 20$.

Reference steroids were purchased from Sigma Chemical Company.

Gonadotropin. - The highly purified gonadotropin, prepared from hypophysis of Oncorhynchus tschawytsha, was a gift of Dr Breton (INRA, Rennes). The technique of purification was described by Breton et al. (1978).

Other chemicals. - Aminoglutethimide (2-p-aminophenyl-2-ethyl-glutarimide) was a gift of Ciba-Geigy (Basel, Switzerland) ; cyanoketone ( $2 \alpha$-cyano- $4,4,17 \alpha$ trimethylandrost-5-ene-17 $\beta$-ol-3-one) was obtained from Sterling-Winthrop.

Incubation. - Testicular fragments were incubated in $15 \mathrm{ml}$ - glass vials containing $3 \mathrm{ml}$ of Eagle's medium (Eagle, 1959) under continuous shaking at $16{ }^{\circ} \mathrm{C}$ (the rearing temperature for at least two weeks before experimentation). An humidified gas mixture $\left(\mathrm{N}_{2} 50 \%, \mathrm{O}_{2} 49 \%, \mathrm{CO}_{2} 1 \%\right)$ was pulsed throughout the experiment $(3$ or $24 \mathrm{~h}$ ). $\mathrm{pH}$ was maintained at 7.9 , the $\mathrm{pH}$ of the coelomic fluid. All the incubations began at 11 a.m. to avoid any possible influence of circadian variation in steroidogenic metabolism. Gonadotropin and labelled steroid were added at the beginning of the experiment. In some experiments, aminoglutethimide $(1 \mathrm{mM})$ or cyanoketone $(0.1 \mathrm{mM})$ was added to the medium $1 \mathrm{~h}$ before the labelled steroid and GTH. $10^{6} \mathrm{dpm}$ of radioactive steroid were added to the unlabelled purified steroid in order to obtain a specific activity averaging $3 \mathrm{Ci} / \mathrm{mmol}$ (steroid concentration : $5 \cdot 10^{-7} \mathrm{M}$ ). Some experiments were performed at a lower $\mathrm{SA}\left(30 \mu \mathrm{Ci} / \mathrm{mmol}\right.$; steroid concentration : $\left.5 \cdot 10^{-5} \mathrm{M}\right)$. A preliminary dose-response curve study of GTH action on $17 \alpha-20 \beta \mathrm{P}$ and androgen synthesis from ${ }^{3} \mathrm{H}$-progesterone (data not shown) led us to use a gonadotropin concentration of $10 \mathrm{ng} / \mathrm{ml}$. Some experiments were performed in the presence of various other concentrations $(50,150$ or $300 \mathrm{ng} / \mathrm{ml})$.

Radioimmunoassay. - Testicular fragments were homogeneized and then extracted by ethanol $80 \%$ and dichloromethane-methanol. Incubation media were extracted by diethylether. The extracts were column-chromatographed on Sephadex LH 20 resin in a dichloromethane-methanol 95 : 5 system. Radioimmunoassay was performed using previously reported methods : Fostier et al. (1981), Jalabert and Fostier (1984), for the assay of $17 \alpha-20 \beta \mathrm{P}$, and Fostier et al. (1982), for the assay of 11-oxotestosterone. The antisera were prepared in rabbits by Fostier from 3-10'-carboxymethyl) oxime BSA conjugates, as previously 
described (see above), the cross reactions of a number of steroids with each of the two antisera are shown in table 1.

TABLE 1

Cross reactions of steroids with antisera to $17_{\alpha}-20 \beta$ and 11-oxotestosterone.

Cross reactivities were measured at the $100 \mathrm{pg}$ level.

\begin{tabular}{lcc}
\hline & $17 \alpha-20 \beta \mathrm{P}$ & 11 -oxo T \\
\hline $17 \alpha$-hydroxy-20 $\beta$-dihydroprogesterone & 100 & 0 \\
$17 \alpha$-hydroxy-20 $\alpha$-dihydroprogesterone & 22 & - \\
$20 \beta$-dihydroprogesterone & 34 & - \\
$5 \beta$-pregnane-3-0l-20 one & 7 & - \\
$17 \alpha$-hydroxyprogesterone & 0 & 0 \\
11 -oxotestosterone & 0 & 100 \\
testosterone & 0 & 9 \\
androstenetrione & - & 10 \\
$11 \beta$-hydroxyandrostenetrione & - & 6 \\
$5 \beta$-dihydrotestosterone & - & 7 \\
$5 \alpha$-androstan-3 $\beta$-17 $\beta$-diol & - & 8 \\
\hline
\end{tabular}

Final antisera dilutions were : $17 \alpha-20 \beta \mathrm{P}, 1: 500,000 ; 11$ oxotestosterone $1: 240,000$ or $1: 300,000$. The intraassay and interassay coefficients of variation were estimated at $6.4 \%$ and $4.1 \%$ respectively, for $17 \alpha-20 \beta P$ assay ; $3.1 \%$ and $9 \%$ respectively, for 11 oxotestosterone assay $(n=11$; confidence limits for $P=0.05)$. The minimum detectable mass was $5 \mathrm{pg} /$ tube for each steroid. Standard curves were plotted on a logit \% bound $v s$ log dose basis. The results were expressed as $\mathrm{ng}$ of steroid produced per $\mathrm{g}$ of incubated testis.

Radiochromatographic studies. - Extraction : before extraction, a cocktail of carriers $(50 \mathrm{mg}$ of each steroid) was added to the medium. The incubation medium was extracted 3 times with diethylether. The homogenized testicular fragments were extracted 3 times by ethanol $80 \%$ and dichloromethane. The organic phase was evaporated to dryness and resuspended in $1 \mathrm{ml}$ of methanol for steroid analysis. After extraction of free steroids, the aqueous phase was digested by $\beta$-glucuronidase (Sigma) (130 Fishman units per vial) for $48 \mathrm{~h}$ at $37^{\circ} \mathrm{C}$. The liberated steroids were extracted by diethylether.

Chromatography. - Thin-layer chromatography was carried out on silica gel plates $60 \mathrm{~F} 254$ (Merck) using the following systems : I) chloroform-ethyl acetate (5: 1); II) chloroform-ethanol (95: 5); III) chloroform-acetone (9: 1) ; IV) chloroform-methanol-water $(88: 12: 1)$; V) chloroform-ethyl acetatemethanol $(45: 45: 10)$; VI) benzene-ethanol $90: 10) ; \mathrm{VII})$ chloroform-ethyl acetate $1: 1 ; \mathrm{VIII}$ ) chloroform-methanol $(96: 4) ;(X)$ cyclohexane-isopropanol $(70: 30) ; X)$ hexane-ethyl acetate $(75: 25) ; X 1)$ chloroform-ethanol $(90: 10)$.

Chromatographic analysis. - The chromatograms were analyzed with a radiochromatograph scanner PANAX XY at a speed of 120 or $600 \mathrm{~mm} / \mathrm{h}$. Steroids were identified by checking the isopolarity of the peak of radioactivity with that of 
the authentic steroid in different systems used successively according to the protocol shown in table 2.

TABLE 2

\begin{tabular}{ll}
\multicolumn{1}{c}{ Steroid } & Successive chromatographies \\
\hline pregnenolone & $\mathrm{I}-\mathrm{I}, \mathrm{II}, \mathrm{X}$ \\
$17 \alpha$-hydroxypregnenolone & $\mathrm{I}-\mathrm{I}, \mathrm{X}, \mathrm{II}$ \\
dihydroepiandrosterone & $\mathrm{I}-\mathrm{I}, \mathrm{II}, \mathrm{X}$ \\
$5 \beta$-pregnane-3,20-dione & $\mathrm{I}$ I, X \\
$17 \alpha$-hydroxyprogesterone & $\mathrm{I}-\mathrm{I}, \mathrm{VI}$ \\
$17 \alpha$-hydroxy-20 $\beta$-dihydroprogesterone & $\mathrm{I}$-I, II, V, IV, VIII, IX \\
androstenedione & $\mathrm{I}-\mathrm{I}, \mathrm{VII}$ \\
$11 \beta$-hydroxyandrostenedione & $\mathrm{II}, \mathrm{XI}$ \\
testosterone & $\mathrm{II}, \mathrm{IV}, \mathrm{III}$ \\
$11 \beta$-hydroxytestosterone & $\mathrm{II}, \mathrm{IV}, \mathrm{III}$ \\
androstenetrione & $\mathrm{I}$-I, IV \\
11 -oxotestosterone & $\mathrm{II}, \mathrm{IV}$ \\
\hline
\end{tabular}

Assays of estrogens were carried out after column chromatography on Dowex AG1-X2 resin, chloride form, 200-400 mesh (Bio-Rad). The columns were prepared according to Adessi et al. (1976). Thin layer chromatography was performed using systems I and III.

Microchemical reactions. - Microchemical reactions were performed according to Bush (1961). Acetylation ( $\Delta 4-\mathrm{C} 19$ steroids, $17 \alpha-20 \beta$ P) was performed with pyridine and acetic anhydrid $\left(20^{\circ} \mathrm{C}, 12 \mathrm{~h}\right)$; acetates were hydrolyzed by $5 \%$ $\mathrm{KOH}$ in methanol $\left(60^{\circ} \mathrm{C}, 1 \mathrm{~h}\right)$; the 17-hydroxy group was oxidized with chromic acid (room temperature, $1 \mathrm{~h}$ in the dark). Androstenedione reduction was performed in the presence of $\mathrm{NaBH}_{4}$.

Recrystallization. - Recrystallizations to a constant isotopic ratio was carried out for $17 \alpha-20 \beta \mathrm{P}$, androstenedione and testosterone in the methanol-water system. After chromatographic purification (see above), the tritiated steroid was mixed with $20 \mathrm{mg}$ of the authentic steroid and a quantity of ${ }^{14} \mathrm{C}$-labelled steroid adjusted so that the ${ }^{3} \mathrm{H} /{ }^{14} \mathrm{C}$ ratio averaged 3 . Three successive recrystallizations were carried out (table 3 ).

\section{TABLE 3}

Recrystallization to a constant isotopic ratio of $17 \alpha-20 \beta P$, androstenedione and testosterone.

\begin{tabular}{lccc}
\hline & Recrystallization & \multicolumn{3}{c}{$3 \mathrm{H} /{ }^{14} \mathrm{C}$ ratio } \\
\cline { 2 - 4 } & $17 \alpha-20 \beta \mathrm{P}$ & androstenedione & testosterone \\
\hline Mother liquor & 3.49 & 3.61 & 3.29 \\
Liquor (L) I & 3.56 & 3.80 & 3.67 \\
Crystals (C) I & 3.47 & 3.82 & 2.86 \\
L II & 3.37 & 3.90 & 3.47 \\
C II & 3.46 & 3.78 & 3.65 \\
L III & 3.55 & 3.92 & 3.27 \\
C III & 3.50 & 3.87 & 3.54 \\
\hline
\end{tabular}


Recrystallization to a constant specific activity was carried out for $17 \alpha$-hydroxypregnenolone, dehydroepiandrosterone, $5 \beta$-pregnane-3,20-dione, 11 $\beta$-hydroxyandrostenedione, $11 \beta$-hydroxytestosterone and androstenetrione. After chromatographic purification, the steroid was mixed with $20 \mathrm{mg}$ of the authentic steroid. Four successive crystallizations were performed in the methanol-water system (table 4).

TABLE 4

Recrystallization to constant specific activity of $17 \alpha$-hydroxypregnenolone, dehydroepiandrosterone,

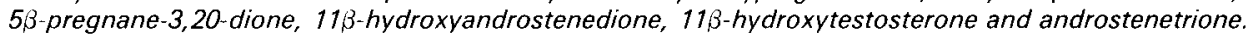

\begin{tabular}{ccccccc}
\hline Crystallization & \multicolumn{5}{c}{ Specific activity (cpm/mg) } \\
\hline & $17 \alpha$ OH $\Delta 5 \mathrm{P}$ & DHEA & $5 \beta \mathrm{Pd}$ & $11 \beta$ OH $\Delta 4 \mathrm{~A}$ & $11 \beta \mathrm{OH} \mathrm{T}$ & A trione \\
I & 18,750 & 15,064 & 25,212 & 46,315 & 58,617 & 21,347 \\
II & 19,068 & 15,470 & 24,430 & 45,064 & 57,503 & 21,645 \\
III & 18,112 & 14,462 & 25,438 & 45,369 & 59,672 & 21,197 \\
IV & 18,003 & 14,416 & 26,371 & 47,241 & 60,688 & 20,841 \\
\hline
\end{tabular}

Expression of results and statistical analysis. - Radioimmunoassay : the in vitro production of $17 \alpha-20 \beta \mathrm{P}$ and 11-oxotestosterone is expressed as $\mathrm{ng}$ of steroid produced by $\mathrm{ng}$ of incubated fragment, after 3 and/or $24 \mathrm{~h}$. Radioisotopic studies: results are expressed as percent conversion rate (radioactivity in $17 \alpha-20 \beta \mathrm{P}$ or pooled $\Delta 4-\mathrm{C} 19$ steroids/radioactivity recovered in the whole of the derivatives $X 100$ ).

As no effect of GTH on the glucuroconjugated steroids synthesis was noticed (see Results), this fraction was not taken into account in the studies of the changes in percent conversion rate from the different precursors under hormone action.

Steroid production and conversion of precursors in the presence or not of gonadotropin were compared using covariance analysis (with blocks).

\section{Results and discussion.}

I. - Action of salmon gonadotropin on testicular production of $17 \alpha-20 \beta P$ and 11-oxotestosterone in vitro.

The dose-response curve of the action of salmon gonadotropin on the production of both $17 \alpha-20 \beta \mathrm{P}$ and 11 -oxotestosterone by rainbow trout testis was determined by Jegou-Le Gac et al. (unpublished data). In the present work we studied only the effect of the addition of one dose of GTH $(10 \mathrm{ng} / \mathrm{ml})$ on the production of these two steroids after $3 \mathrm{~h}$ (duration of the experiments performed in the presence of radiolabelled steroids) and after $24 \mathrm{~h}$. Steroid concentrations were measured by radioimmunoassay in the incubation medium and also in the incubated tissular fragment at the end of the incubation. These concentrations 
were compared in incubations performed with or without addition of gonadotropin (fig. 1).

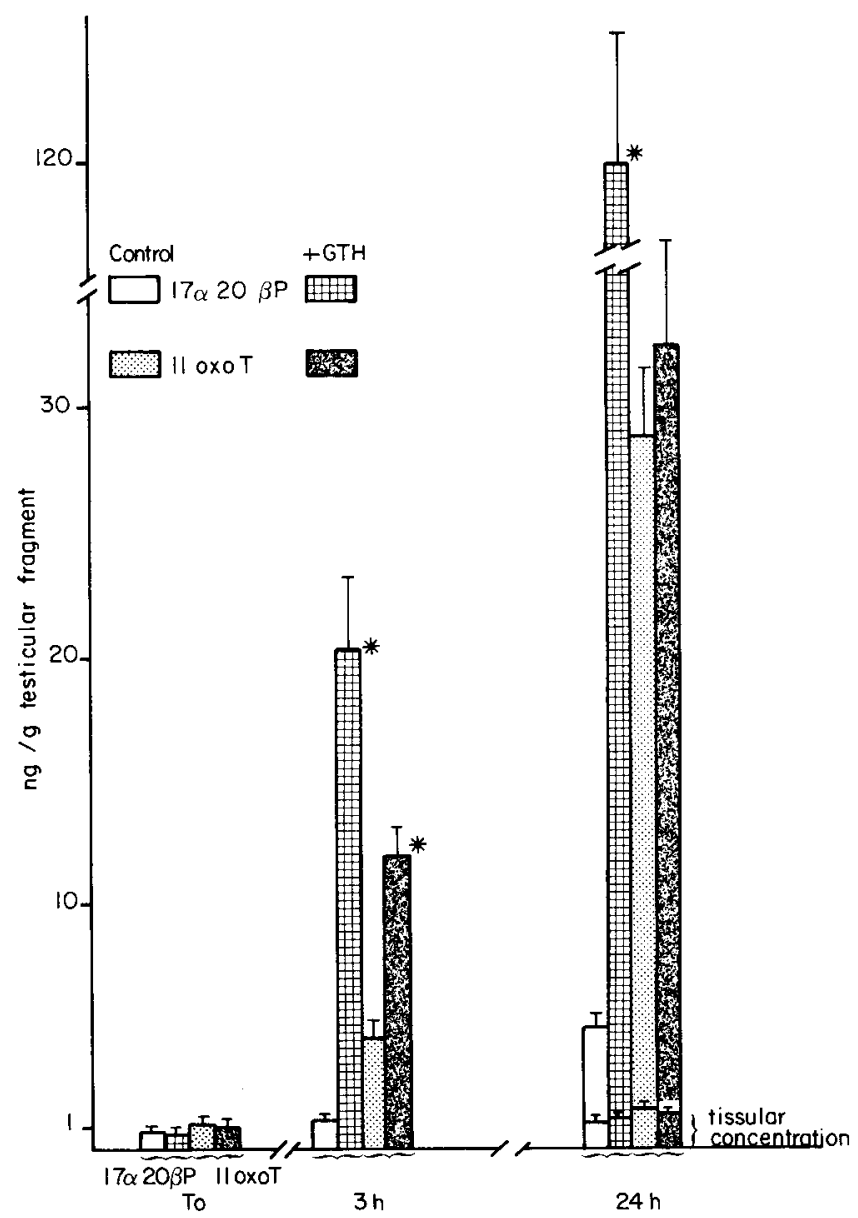

FIG. 1. - Effect of gonadotropin $(10 \mathrm{ng} / \mathrm{ml})$ on the production of $17 \alpha-20 \beta \quad P$ and 11 -oxotesterone by the rainbow testis in vitro after 3 and $24 \mathrm{~h}$ incubation. Radioimmunoassay. Means of 4 incubations \pm S.E.M. $;\left(^{*}\right)$ difference significative at the 0.001 level with control incubation.

As soon as $3 \mathrm{~h}$ after the beginning of the incubation, $17 \alpha-20 \beta \mathrm{P}$ and 11-oxotestosterone concentrations increased significantly in the incubation media when testicular fragments were cultured in the presence of GTH. After $24 \mathrm{~h}$, the concentrations of both steroids were higher in incubation media in the presence of GTH, but the difference with the control was greater for $17 \alpha-20 \beta \mathrm{P}$ than for 11-oxotestosterone, indicating that, at the concentration used, GTH preferentially favoured the synthesis of the progestin. The concentration of the steroids in their conjugated form was not studied as it was examinated using radioisotopic methods (see below). Our results agree with those of Ueda et al. (1983) as far as the effect of GTH on $17 \alpha-20 \beta \mathrm{P}$ is concerned. Yet, these authors observed no, if

Reproduction, Nutrition, Développement $n^{\circ} 2 A \cdot 87 .-8$ 
any, gonadotropin action at the concentration $(10 \mathrm{ng} / \mathrm{ml})$ we used ; this could be due to the fact that we employed a more highly purified fraction of the hormone.

\section{II. - Biosynthetic routes of androgens and $17 \alpha-20 \beta P$ in rainbow trout testis.}

Many data have already been published (Arai and Tamaoki, 1967 ; Kime, 1980 ; Van den Hurk et al., 1982 ; Dépêche and Sire, 1982), but information is lacking in regard to the respective roles of $\Delta 5$ and $\Delta 4$ routes for androgen synthesis and to several enzymatic steps.

The percentages of derivatives recovered after $3 \mathrm{~h}$ of incubation in the presence of various $\Delta 5$ and $\Delta 4$ tritiated steroids ( 3 to 6 incubations per precursor) are reported in table 5 .

In incubations performed in the presence of pregnenolone $(\Delta 5 \mathrm{P})$, the formation of $17 \alpha$-hydroxypregnenolone and dehydroepiandrosterone indicated that the $\Delta 5$ route of synthesis operated in rainbow trout testis.

The major $\Delta 4-C 21$ steroids synthesized from $\Delta 5 \mathrm{P}$ were $17 \alpha$-hydroxyprogesterone and $17 \alpha-20 \beta \mathrm{P}$. In addition, there was a low yield of 5-pregnane3,20-dione synthesis. The major $\Delta 4-C 19$ steroids synthesized (i.e. « androgens ») were testosterone, $11 \beta$-hydroxytestosterone and 11-oxotestosterone. Only traces of $11 \beta$-hydroxyandrostenedione and androstenetrione were detected.

In incubations performed in the presence of progesterone, radioactivity was mainly recovered in $17 \alpha-20 \beta \mathrm{P}, 11 \beta$-hydroxytestosterone and 11-oxotestosterone, as previously described (Dépêche and Sire, 1982 ; see also Fostier et al., 1983). In our incubations, androstenedione and 11/-hydroxyandrostenedione did not accumulate.

In incubations performed in the presence of $17 \alpha$-hydroxyprogesterone (17 $\alpha-\mathrm{OH} \Delta 4 \mathrm{P}), 17 \alpha-20 \beta \mathrm{P}$ represented $70 \%$ of the steroids synthetized. To specify the degree of reversibility of the reduction reaction of $17 \alpha-\mathrm{OH} \Delta 4 \mathrm{P}$, we incubated testes in the presence of labelled $17 \alpha-20 \beta \mathrm{P}$. In these conditions, a very low percentage of labelled $17 \alpha-\mathrm{OH} \Delta 4 \mathrm{P}$ was formed. In addition, no $\Delta 4-\mathrm{C} 19$ were formed, indicating that the 17-20 lyase did not convert $17 \alpha-20 \beta \mathrm{P}$. This suggests that $17 \alpha-20 \beta \mathrm{P}$ would not be a precursor for androgens in rainbow trout testis, as previously hypothetized by Scott and Baynes (1982).

In incubations performed in the presence of either androstenedione or testosterone, high percentages of 11-hydroxytestosterone and 11-oxotestosterone were found. This confirms that these steroids are the main androgens synthesized in rainbow trout testis (see Fostier et al., 1983).

In incubations performed in the presence of $7(\mathrm{n})-{ }^{3} \mathrm{H}$-androstenedione or $7(n)^{3} \mathrm{H}$-testosterone, there was no trace of either estrone or $17 \beta$-estradiol, suggesting the lack of any noticeable aromatase activity in rainbow trout testis (at the stage of the reproductive cycle studied).

In incubations performed in the presence of androstenetrione, $90 \%$ of the steroid production was represented by 11-oxotestosterone.

On the whole, our results confirm previous steroid biosynthetic pathways proposed in the rainbow trout testis (Dépêche and Sire, 1982). Moreover, they show, for the first time, the presence of an active $\Delta 5$ route of androgen synthesis, 


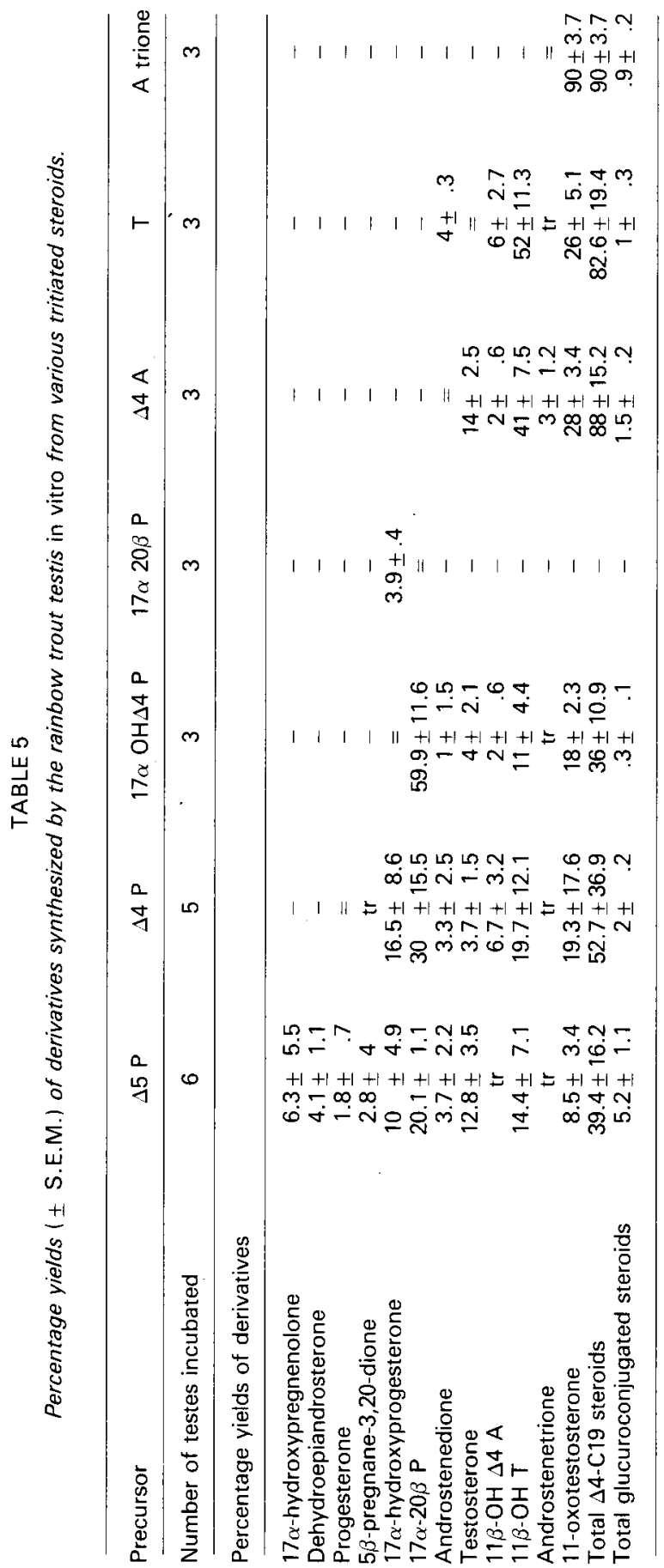


at least at the terminal stage of the spermatogenetic cycle. More elaborate analytical methods are required to confirm the absence of estrogen formation. In any case, if this synthesis exists, it would be very discrete.

This study provides useful information on the selection of a convenient methodology for examining the action of GTH on some enzyme activities in rainbow trout testis.

In alt incubations, the total amounts of glucuroconjugated steroids recovered was low (generally $\leq 5 \%$ ). The percentages were smaller than those reported by Kime (1979) for incubations in the presence of pregnenolone, androstenedione or testosterone at the same incubation temperature $\left(16^{\circ} \mathrm{C}\right)$.

\section{III. - Action of salmon gonadotropin on the conversion of labelled steroids in rainbow trout testis.}

1) Pregnenolone conversion (fig. 2). - In the presence of GTH, the apparent rate of pregnenolone conversion decreased. The rate of formation of $17 \alpha-20 \beta \mathrm{P}$ and $\Delta 4-C 19$ steroids was reduced at the same extent. To specify the role of an isotopic dilution of pregnenolone by increased formation of endogenous precursors, we incubated testes in the presence of aminoglutethimide $(1 \mathrm{mM})$. This compound inhibits the conversion of cholesterol by blocking its 20-hydroxylation (Kahnt and Neher, 1966). In these condiţions, the conversion rate of pregnenolone returned to the control level. This suggests that the decrease in the apparent conversion rate in the presence of GTH was due to activation of pregnenolone precursor (cholesterol and derivatives) conversion. In the presence

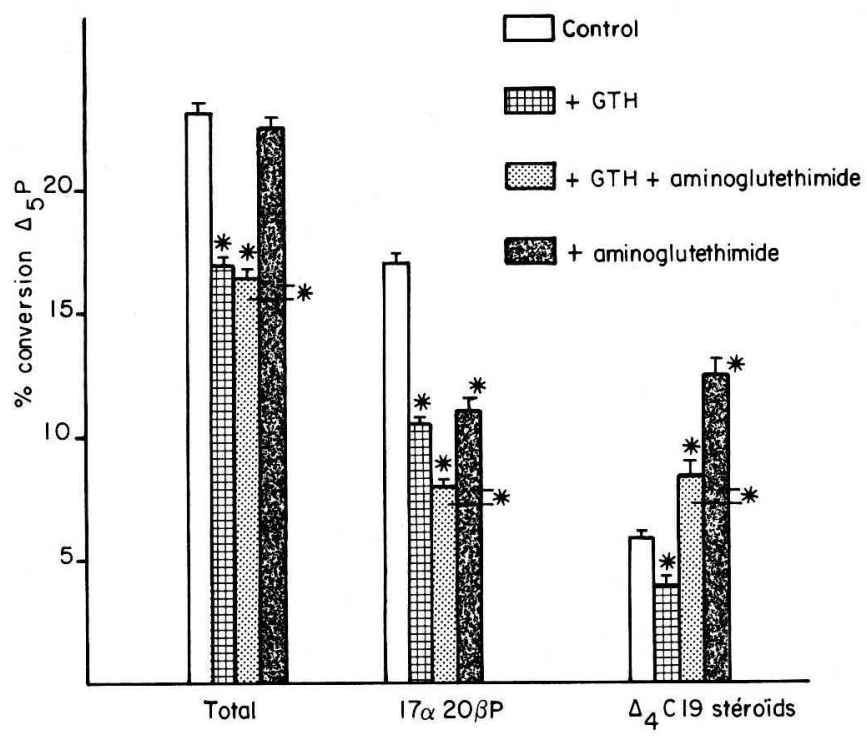

FIG. 2. - Effect of gonadotropin $(10 \mathrm{ng} / \mathrm{ml})$ on the conversion of ${ }^{3} \mathrm{H}$-pregnenolone $\left(5.10^{-7} \mathrm{M}\right)$ by the rainbow trout testis in vitro, in the presence or not of aminoglutethimide $(1 \mathrm{mM})$. Percents of conversion into total recovered derivatives or into $17 \alpha-20 \beta \mathrm{P}$ and $\Delta 4-\mathrm{C} 19$ steroids. Means of 3 incubations \pm S.E.M. $;\left(^{*}\right)$ if not otherwise indicated : difference significative at the 0.02 level with control incubations. 
of $\mathrm{GTH}$ alone, the ratio $17 \alpha-20 \beta \mathrm{P} / \Delta 4-\mathrm{C} 19$ steroids was not changed in comparison with the control. In contrast, in the presence of both GTH and aminoglutethimide this ratio decreased by about one-third. This suggests that GTH stimulated enzyme activities converting pregnenolone into $\Delta 4-\mathrm{C} 19$ steroids. These enzymes may be $\Delta 5-3 \beta$-hydroxysteroid oxidoreductase as well as $17 \alpha$ hydroxylase or 17-20 lyase. The selective effect on $\Delta 4-\mathrm{C} 19$ steroids formation appears to favour the existence of gonadotropic stimulation of the enzymes of the $\Delta 5$ route that convert $\Delta 5 \mathrm{P}$ into androgen precursors $(17 \alpha$ OHase and $17-20$ lyase).

2) Progesterone conversion (fig. 3). - When GTH was added in the incubations performed in the presence of tritiated progesterone, apparent $17 \alpha$ $20 \beta P$ synthesis was strongly increased $(P \geq 0.02)$. We did not observe any effect of the addition of the hormone on the apparent synthesis of $\triangle 4-C 19$ steroids. This result suggests that GTH acts according to a differential pattern in the formation of the two types of steroids. The increase in $17 \alpha-20 \beta \mathrm{P}$ synthesis could be due to a stimulation of $17 \alpha$-hydroxylase and/or $20 \beta$-OHSOR that convert progesterone into $17 \alpha-20 \beta \mathrm{P}$.

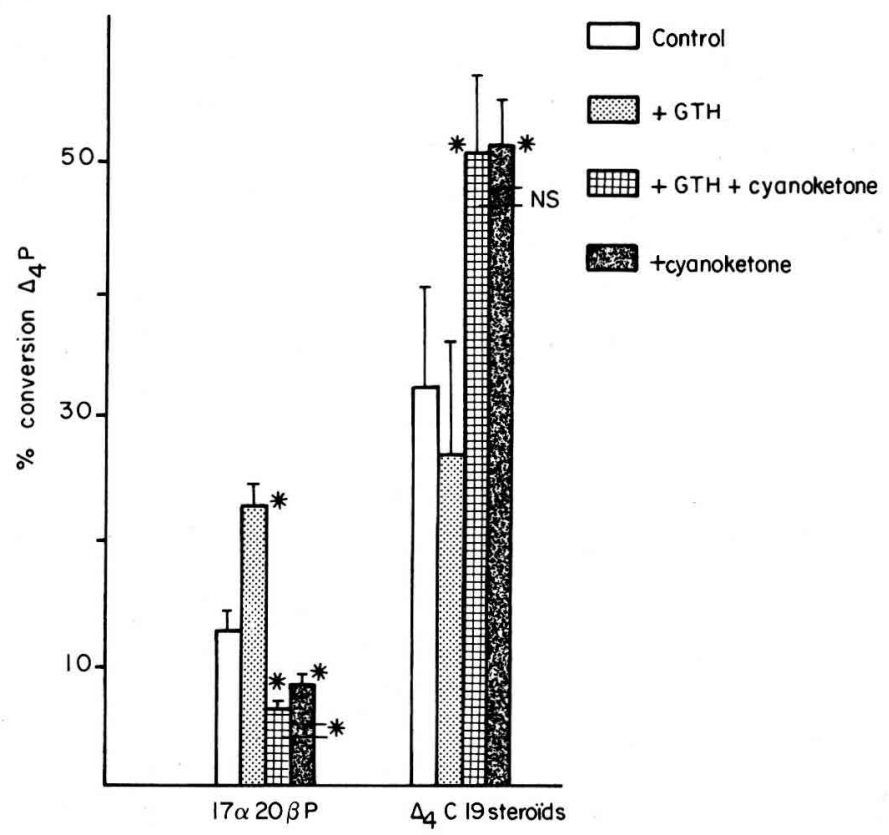

FIG. 3. - Effect of gonadotropin $(10 \mathrm{ng} / \mathrm{ml})$ on the conversion of ${ }^{3} \mathrm{H}$-progesterone $\left(5.10^{-7} \mathrm{M}\right)$ into $17 \alpha-20 \beta$ and $\Delta 4-C 19$ steroids by the rainbow trout testis in vitro, in the presence or not of cyanoketone $(0.1 \mathrm{mM})$. Means of 6 incubations \pm S.E.M. ; $(*)$ if not otherwise indicated, difference significative at the 0.02 level with control incubations.

To test the effect of suppressing (or reducing) the formation of progesterone from endogenous unlabelled precursors, we incubated testes in the presence of $0.1 \mathrm{mM}$ cyanoketone. This steroid inhibits $\mathrm{C} 21$ - and $\mathrm{C} 19-3 \beta-\mathrm{OHSOR}$ (Goldman and Sheth, 1973). When testes were incubated in the presence of both tritiated 
progesterone and cyanoketone, the apparent synthesis of $17 \alpha-20 \beta \mathrm{P}$ was significantly decreased, whereas the apparent synthesis of $\Delta 4-C 19$ steroids was significantly increased. The addition of GTH reinforced the effect of cyanoketone on the apparent synthesis of $17 \alpha-20 \beta \mathrm{P}$ but not on the synthesis of $\Delta 4-\mathrm{C} 19$ steroids. It could be considered that cyanoketone had an inhibitory action on $20 \beta$-OHSOR activity. Moreover, it may be hypothetized that the flux of nonlabelled endogenous precursors (whose formation was stimulated by GTH) was stronger for $\Delta 4-\mathrm{C} 21$ than for $\Delta 4-\mathrm{C} 19$ steroids formation. So, a major flux from $\Delta 5$ steroids to $17 \alpha-20 \beta \mathrm{P}$ could exist in the testis.

3) 17 $\alpha$-hydroxyprogesterone conversion (fig. 4). - In incubations performed in the presence of $17 \alpha$-hydroxyprogesterone, the addition of GTH slightly but significantly $(P \leq 0.02)$ decreased the apparent conversion rate of the precursor. This decrease was due only to a reduction of apparent $17 \alpha-20 \beta$ P synthesis. To specify the role of an isotopic dilution effect, resulting from an increased conversion of endogenous $17 \alpha$-hydroxyprogesterone precursors, we incubated testes in the presence of a greater amount of the steroid $\left(5.10^{-5} \mathrm{M}\right)$. In these conditions, the apparent conversion of the precursor was considerably reduced.

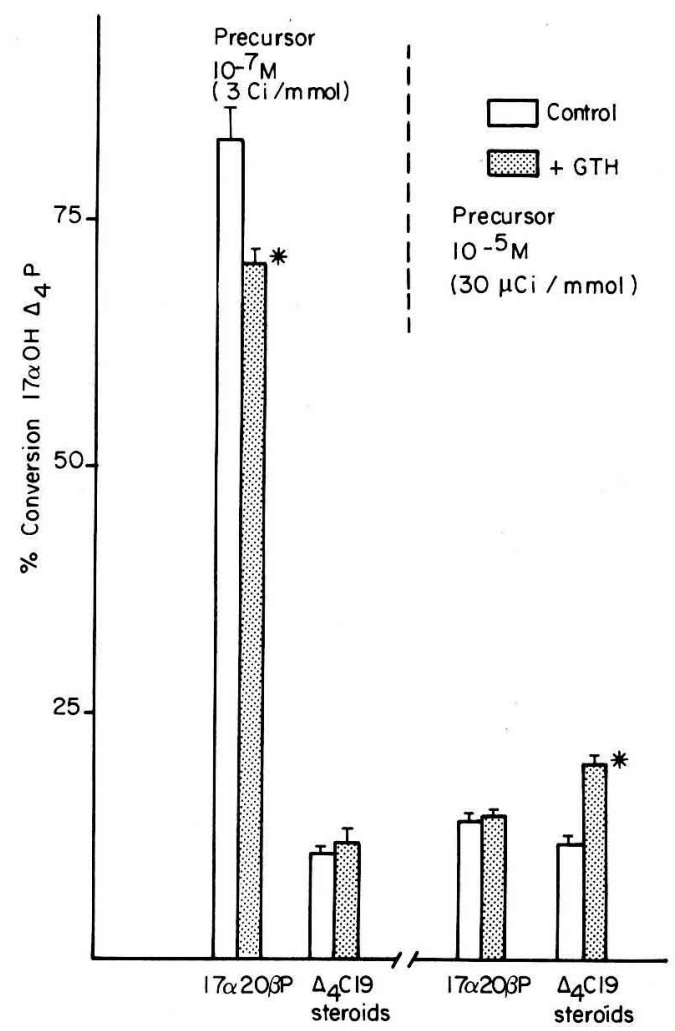

FIG. 4. - Effect of gonadotropin $(10 \mathrm{ng} / \mathrm{ml})$ on the conversion of $3 \mathrm{H}$-hydroxyprogesterone $\left(5.10^{-7}\right.$ or 5.10-6 M) into $17 \alpha-20 \beta P$ and $\Delta 4-C 19$ steroids by the rainbow trout testis in vitro. Means of 5 incubations \pm S.E.M. $;\left(^{*}\right)$ difference significative at the 0.05 level with control incubations. 
The addition of GTH did not affect apparent $17 \alpha-20 \beta$ P synthesis, but increased that of $\triangle 4-C 19$ steroids. These results show that GTH did not inhibit the activity of 17-20 lyase when $17 \alpha-20 \beta \mathrm{P}$ formation was stimulated. So, this stimulatory effect of GTH does not appear to correspond to a shift of the biosynthetic flux consecutive to inhibition of an enzyme activity, as described in other experimental models like the adult mammalian testis under conditions of gonadotropin-induced desensitization (Haour et al., 1982). The decrease in the apparent synthesis of $17 \alpha-20 \beta \mathrm{P}$ under the action of GTH alone could be due to increased conversion of endogenous precursors of $17 \alpha$-hydroxyprogesterone owing to the stimulation of the enzyme activities previously mentioned (see above : III- 1 and 2).

4) Glucuroconjugated steroid synthesis. - We wished to check whether adding GTH, in our experimental conditions, would affect the formation of glucuroconjugated steroids; to do so, we incubated testes in the presence of tritiated progesterone and various concentrations of GTH $(10,50,150$ and $300 \mathrm{ng} / \mathrm{ml}$ ) (table 6). No significant changes in the percentage yields of the total glucuroconjugated steroids recovered were observed in comparison with control incubations, whatever the GTH concentration. So, in our experimental conditions, GTH appeared to have no effect on testicular glucuronyl-transferase activity in the rainbow trout (at the spermatogenetic stage examined). It cannot be excluded that, in other conditions, as under long-term stimulation, GTH might induce the changes in the level of glucuroconjugated steroid synthesis observed by Kime and Manning (1982) during the annual reproductive cycle.

\section{TABLE 6}

Effect of gonadotropin addition on the formation of glucuroconjugated steroids synthesized from ${ }^{3} \mathrm{H}$ progesterone.

\begin{tabular}{|c|c|c|c|c|c|}
\hline & \multicolumn{5}{|c|}{ Gonadotropin concentration $(\mathrm{ng} / \mathrm{ml})$} \\
\hline & 0 & 10 & 50 & 150 & 300 \\
\hline $\begin{array}{l}\text { Glucuroconjugated steroids }(\% \text { of } \\
\text { total recovered steroids) }\end{array}$ & $17.5 \pm 4.2$ & $16.9 \pm 3$ & $13.2 \pm 3$ & $17.3 \pm 7.6$ & $14.4 \pm 4.3$ \\
\hline
\end{tabular}

\section{Discussion.}

Taken together, our data show that gonadotropin action on rainbow trout testis in vitro, in conditions of increased $17 \alpha-20 \beta$ P production, resulted in the stimulation of several enzyme activities. In the steroid biosynthetic pathway, the first enzymatic step that appeared to be regulated by GTH was that leading to pregnenolone formation. This might be due to an acceleration of cholesterol sidechain cleavage (20-hydroxylation), as shown in other models of the Vertebrate testis (Gower, 1984). Other enzymatic steps also appeared to be under positive GTH control : the conversion of $\Delta 5$ - into $\Delta 4$ steroids $(\Delta 5-3 \beta$-OHSOR) and the transformation of progesterone into $17 \alpha-20 \beta \quad \mathrm{P} \quad(17 \alpha$-hydroxylase and 
$20 \beta$ OHSOR). Among these enzymes, $\Delta 5-3 \beta-O H S O R$ was previously proposed as a target for GTH action on the testis of various teleosts under in vivo or in vitro conditions (Fostier et al., 1983). Such multiple enzymatic modifications under gonadotropin action are known, for instance in the mammalian testis in conditions of LH-hCG desensitization. So, in the adult testis of rat, mouse or man subjected to hCG action, $17 \alpha$-hydroxylase first appeared to be stimulated in an early phase, leading to increased testosterone production and then to a loss of 17-20 lyase activity that caused a fall in androgen synthesis (Forest et al., 1979 ; Haour et al., 1982). In conditions of increased $17 \alpha-20 \beta \mathrm{P}$ production, in our experimental model, 17-20 lyase activity did not appear to be inhibited, whereas various other enzymes were positively controlled. Thus, $17 \alpha-20 \beta \mathrm{P}$ production does not seem to be a consequence of restricted androgen synthesis due to a shift in the biosynthetic pathway.

The mechanisms involved in the multiple control of enzyme activities by a single gonadotropin raise difficult problems. Some new concepts have been presently developed in mammals. In neonatal porcine testes (Nakajin et al., 1981), and perhaps in neonatal-prepuberous rat testes (Cheng, 1985), 17 $\alpha$-hydroxylase and 17-20 lyase activities seem to result from a single cytochrome P-450, a situation that would not exclude the existence of different control systems for the two enzyme activities.

From a physiological point of view, it should be emphasized that in vivo studies showed that, in the rainbow trout, both 11-oxotestosterone (Fostier et al., 1982) and $17 \alpha-20 \beta \mathrm{P}$ (Ueda et al., 1983) plasmatic values are high at the end of the annual reproductive cycle when the gonadotropin concentration reaches its maximum, and that in vitro, in the amago salmon, simultaneous increase in the plasmatic levels of these steroids are induced by injection of SGA (chum salmon gonadotropin) (Ueda et al., 1985). Moreover, comparisons between in vivo and in vitro situations are complicated by the existence of extra-testicular sources of androgens that have to be considered, and especially the interrenal gland (cf. the " interrenal-liver-gonad axis" proposed by Kime, 1978 ; see also Schulz, 1985).

In rainbow trout, the identification of the cellular origin of the different steroids synthesized by the testis and the possibility of obtaining pure preparations of isolated Leydig and Sertoli cells are prerequisites for more advanced research on the gonadotropic regulation of steroidogenesis. At the present time, the difficulties encountered by various workers have not been overcome. Spermatozoa have been proposed as the cellular source of $17 \alpha-20 \beta \mathrm{P}$ in rainbow trout testis (Ueda et al., 1984; Schulz, 1984). According to these authors, spermatozoa would possess $20 \beta$-OHSOR activity. Our present results do not agree with this view, as $20 \beta$-OHSOR appears to be a GTH-dependent enzyme activity and the location of GTH receptors on germ cells is very unlikely. Alternatively, it might be suggested that another cell type in the testis possesses gonadotropin-responsive $20 \beta$-OHSOR. This point needs further clarification.

The present work contributes to the problem of the physiological significance of testicular $17 \alpha-20 \beta \mathrm{P}$ production. It is shown that this steroid can no longer be considered as a precursor of androgen synthesis, as previously hypothesized by Scott and Baynes (1982). The fact that increased progestin production under 
gonadotropin stimulation in vitro strongly evokes the physiological situation existing at the end of the reproductive cycle, has encouraged a more thorough examination of the recent data involving progestin in the spermiation processes (Ueda et al., 1983). Such a view does not exclude a possible cooperative role of 11-oxotestosterone, whose plasma levels were shown to be related to sperm production in rainbow trout (Fostier et al., 1982). The role of 11-oxotestosterone in activating $20 \beta$-OHSOR activity was studied in rainbow trout by Leprêtre and Dépêche (unpublished data). The results of their study suggest that androgen may be a regulator of progestin synthesis in the testis and that $17 \alpha-20 \beta \mathrm{P}$ production could be under double control : extratesticular (gonadotropic) and intratesticular (local action of 11-oxotestosterone).

Recu en novembre 1986. Accepté en janvier 1987.

Aknowledgements. - The authors are grateful to Dr Breton (I.N.R.A., Rennes) for the gift of the highly purified gonadotropin and to Dr Fostier (I.N.R.A., Rennes) for advice and kind cooperation. Thanks are also due to Mrs A. Daifuku for assistance in editing the text.

This work was supported by a grant from D.G.R.S.T. as a part of the "concerted action on nervous and endocrine regulation of reproduction " (aid $n^{\circ} 8.07 .0344$ ).

Résumé. Action in vitro de la gonadotropine de saumon sur la synthèse des androgènes et d'une progestine la $17 \alpha$-hydroxy-20 $\beta$-dihydroprogestérone dans le testicule de la truite arc-en-ciel (Salmo gairdneri).

In vitro, une fraction hautement purifiée de la gonadotropine de saumon $(10 \mathrm{ng} / \mathrm{ml}$, durée d'incubation de $3 \mathrm{~h}, 16^{\circ} \mathrm{C}$ ) augmente à la fois la production de 11-oxotestostérone et

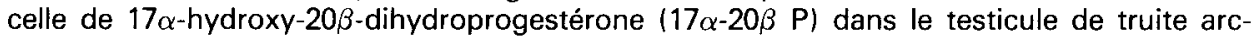
en-ciel. Toutefois, la synthèse de progestine apparaît stimulée de façon préférentielle. Après un réexamen des voies de la biosynthèse des androgènes et de la $17 \alpha-20 \beta \mathrm{P}$ en mettant en cuvre des techniques radiochromatographiques, on a étudié l'effet de l'addition de la gonadotropine sur la conversion de la prégnénolone, de la progestérone et de la $17 \alpha$ hydroxyprogestérone. Cette étude montre que l'hormone a une action de caractère pléiotropique sur les activités enzymatiques de la stéroïdogenèse testiculaire. Les étapes suivantes de la biosynthèse des stéroïdes apparaissent sous contrôle gonadotrope positif : la formation de la prégnénolone, la conversion des stéroïdes en $\Delta 5$ en stéroïdes en $\Delta 4$ (activité $\Delta 53 \beta$ OHSOR), la $17 \alpha$-hydroxylation de la progestérone, la $20 \beta$-oxydoréduction et le clivage en 17-20 de la 17 $\alpha$-hydroxyprogestérone. La prévalence de la synthèse de $17 \alpha-20 \beta \mathrm{P}$ (qui n'est pas convertie en androgènes par la 17-20 lyase) apparaît comme la conséquence d'une action différentielle de la gonadotropine sur un ensemble multienzymatique sur lequel elle exerce un contrôle positif. Elle n'implique aucune inhibition d'une étape de la stéroïdogenèse conduisant à une dérive du flux de biosynthèse.

\section{References}

ADESSI G., GOUTTE-COUSSIEU C., NHUANT T. Q., JAYLE M. F., 1976. Aromatisation de la testostérone par le placenta de cobaye in vitro. Biochimie, 58, 373-375.

ARAI R., TAMAOKI B., 1967. Steroid biosynthesis in vitro by testes of rainbow trout, Salmo gairdneri. Gen. comp. Endocrinol., 8, 305-313.

BAYNES S. M., SCOTT A. P., 1985. Seasonal variations in milt production and in plasma concentration of sex steroids of male rainbow trout (Salmo gairdneri). Gen. comp. Endocrinol., 57. $150-160$. 
BILLARD R., ESCAFFRE A. M., 1975. Identification des stades de la spermatogenèse de la truite fario d'après la morphologie des gonades et la spermiation. Bull. fr. Piscicult.,47, 111-116.

BRETON B., PRUNET P., REINAUD P., 1978. Sexual differences in salmon gonadotropin. Ann. Biol. anim. Bioch. Biophys., 18, 759-765.

BUSH I. H., 1961. The chromatography of steroids. Pergamon Press, New York.

CHENG H. C., 1985. Acute effect of human chorionic gonadotropin (hCG) on $17 \alpha$-hydroxylase and C17-20 lyase activity in neonatal or prepubertal reat testis. J. Steroid. Biochem., 14, 1061. 1067.

DÉPÉCHE J., SIRE O., 1982. In vitro metabolism of progesterone and $17 \alpha$-hydroxyprogesterone in the testis of the rainbow trout, Salmo gairdneri Rich., at different stages of spermatogenesis. Reprod. Nutr. Dévelop., 22, 427-438.

EAGLE H., 1959. Amino acid metabolism in mammalian cell cultures. Science, 130, 432-437.

FOREST M. G., LECOQ A., SAEZ J. M., 1979. Kinetics of human gonadotropin-induced steroidogenic response of the human testis. II. Plasma $17 \alpha$-hydroxyprogesterone, androstenedione, estrone, and $17 \beta$-estradiol : evidence for the action of human chorionic gonadotropin on intermediate enzymes implicated in steroid biosynthesis. J. clin. Endocr. Metab., 49, 284-291.

FOSTIER A., BRETON B., JALABERT B., MARCUZZI O., 1981. Evolution des niveaux plasmatiques de la gonadotropine glycoprotéique et de la $17 \alpha$-hydroxy-20 $\beta$-dihydroprogesterone au cours de la maturation et de l'ovulation chez la truite arc-en-ciel (Salmo gairdneri). $C$. $R$. Acad. Sci., ser. III, 293, 817-820.

FOSTIER A., BILLARD R., BRETON B., LEGENDRE M., MARLOT S., 1982. Plasma 11-oxotestosterone and gonadotropin during the beginning of spermiation in rainbow trout (Sa/mo gairdneri R.). Gen. comp. Endocrinol., 46, 428-434.

FOSTIER A., JALABERT B., BILLARD R., BRETON B., ZOHAR Y., 1983. The gonadal steroids, 277-372. In HOAR W. S., RANDALL D. J.,DONALDSON E. M., Fish physiology, IX, part A. Acad. Press, New York.

GOLDMAN A. S., SHETH K., 1973. Inhibitors of human placental C 19 and C 21-3ß-hydroxysteroid dehydrogenase. Biochim. Biophys. Acta, 315, 233-249.

GOWER D. B., 1984. Regulation of steroidogenesis. In MAKIN H. L. Y., Biochemistry of steroid hormones, ed., 2nd ed., Blackwell Sc. Pub., Oxford.

HAOUR F., DRAY F., MATHER J. P., 1982. In vivo and in vitro response of Leydig cells to acute stimulation by hCG. Ann. N. Y. Acad. Sci., 383, 231-348.

IDLER D. R., NG T. B., 1983. Teleost gonadotropins: isolation, biochemistry, and function, 187-221. In HOAR W. S., RANDALL D. J., DONALDSON E. M., Fish physiology, IX, part A, Acad. Press, New York.

JALABERT B., FOSTIER A., 1984. The modulatory effect in vitro of oestradiol-17 $\beta$, testosterone or cortisol on the output of $17 \alpha$-hydroxy-20 $\beta$-dihydroprogesterone by rainbow trout (Salmo gairdneri) ovarian follicles stimulated by the maturational gonadotropin s-GtH. Reprod. Nutr. Dévelop., 24, 127-136.

KAHNT F. W., NEHER R., 1966. Über die adrenale Steroide-Biosynthese in vitro. III. Selektive Hemmung der Nebennieren Rinden-Funktion. Helv. chim. Acta, 49, 725-732.

KIME D. E., 1978. The hepatic catabolism of cortisol in teleost fish-adrenal origin of 11-oxotestosterone precursors. Gen. comp. Endocrinol., 35, 322-328.

KIME D. E., 1979. The effect of temperature on the testicular steroidogenic enzymes of the rainbow trout, Salmo gairdneri. Gen. comp. Endocrinol., 39, 290-296.

KIME D. E., 1980. Comparative aspects of testicular androgen biosynthesis in non-mammalian vertebrate, 17-31. In DELRIO G., BRACHET, J., Steroids and their mechanism of action in non-mammalian vertebrates, Raven Press, New York.

KIME D. E., HEWS E. A., 1978. In vitro biosynthesis of 11 $\beta$-hydroxy- and 11-oxotestosterone by testes of the pike Esox lucius and the perch Perca fluviatilis. Gen. comp. Endocrinol., 36. 604-608

KIME D. E., MANNING N. J., 1982. Seasonal patterns of free and conjugated androgens in the brown trout Salmo trutta. Gen. comp. Endocrinol., 48, 222-231.

NAKAJIN S., SHIVELY J. E., YUAN P.-M., HALL P. F., 1981. Microsomal cytochrome P-450 from neonatal pig testis: two enzymatic activities (17 $\alpha$-hydroxylase and $\mathrm{C} 17-20$ lyase) associated to one protein. Biochemistry, 20, 4037-4042. 
NG T. B., IDLER D. R., 1980. Gonadotropic regulation of androgen production in flounder and Salmonids. Gen. comp. Endocrinol., 42, 25-38.

NORYMBERSKI J. K., WOODS G. F., 1955. Partial reduction of steroid hormones and related substances. J. amer. Chem. Soc., 77, 3426-3430.

OZON R., 1972. Androgens in fishes, amphibians, reptiles and birds, 329-389. In IDLER D. R., Steroids in non-mammalian vertebrates. Acad. Press, New York and London.

SCHULZ R., 1984. Serum levels of 11-oxotestosterone in male and $17 \beta$-estradiol in female rainbow trout (Salmo gairdneri) during the first reproductive cycle. Gen. comp. Endocrinol., 56, 111120

SCHULZ R., 1985. Measurement of five androgens in the blood of immature and maturing male rainbow trout, Salmo gairdneri (Richardson). Steroids, 46, 717-725.

SCOTT A. P., BAYNES S. M., 1982. Plasma levels of sex steroids in relation to ovulation and spermiation in rainbow trout (Salmo gairdneri), 103-106. In RICHTER C. J. J., GOODS H. J. T., Proc. int. Symp, reproductive physiology of fish, Wageningen, PUDOC, The Netherlands.

UEDA H., YOUNG G., CRIM L. W., KAMBEGAWA A., NAGAHAMA Y., 1983. 17 $\alpha$-20 $\beta$-dihydroxy-4pregnen-3-one : plasma levels during sexual maturation and in vitro production by the testes of amago salmon (Oncorhynchus rhodurus) and rainbow trout (Salmo gairdneri). Gen. comp. Endocrinol., 51, 106-112.

UEDA H., KAMBEGAWA A., NAGAHAMA Y., 1984. In vitro 11-ketotestosterone and 17 $\alpha$-20 $\beta$ dihydroxy-4-pregnen-3-one production by testicular fragments and isolated sperm of rainbow trout, Salmo gairdneri. J. exp. Zool., 231, 435-439.

UEDA H., KAMBEGAWA A., NAGAHAMA Y., 1985. Involvement of gonadotrophin and steroid hormones in spermiation in the amago salmon, Oncorhynchus rhodurus, and goldfish, Carassius auratus. Gen. comp. Endocrinol., 59, 24-30.

VAN DEN HURK R., LAMBERT J. G. D., PEUTE J., 1982. Steroidogenesis in the gonads of rainbow trout fry (Salmo gairdneri) before and after the onset of gonadal sex differenciation. Reprod. Nutr. Dévelop., 22, 413-425. 